J. Clin. Chem. Clin. Biochem.

Vol. 20,1982 , pp. 553-556

\title{
Comparison of Commercially Available RIA and ELISA Kits for the Determination of Total and Specific IgE in Human Sera
}

\author{
By L. A. M. J. Houben and P. L. B. Bruynzeel
}

Department of Lung Diseases, University Hospital Utrecht, The Netherlands

(Received June 25, 1981/March 3, 1982)

Summary: In this study two commercially available ELISA kits were compared with one commercially available RIA kit for the detection of total serum IgE.

One of the ELISA kits was inferior to the others in the IgE region below $10 \mathrm{IU} / \mathrm{ml}$.

In our hands the commercially available ELISA and RIA kits were equally good for the detection of specific IgE.

Vergleich kommerziell erhältlicher RIA- und ELISA-Testbestecke zur Bestimmung des gesamten und spezifischen IgE im Serum des Menschen

Zusammenfassung: In dieser Studie wurden zwei handelsübliche ELISA-Kits mit einem handelsüblichen RIA-Kit für die Bestimmung des gesamten IgE im Serum verglichen.

Einer der ELISA-Kits war dem anderen im IgE-Bereich unter $10 \mathrm{IE} / \mathrm{ml}$ unterlegen.

Im Ergebnis waren die handelsüblichen ELISA- und RIA-Kits für die Bestimmung von spezifischem IgE gleich gut.

\section{Introduction}

For the detection of total IgE in human sera different radioimmunoassay methods have been developed commercially, i.e. the RIST (= radio-immunosorbent test) and the PRIST (= paper-radio-immunosurbent test) $(1,2)$. Since the PRIST is the most sensitive system, this kit is now generally used for the detection of total $\operatorname{IgE}(2)$. A similar radioimmunoassay has been developed for the detection of specific IgE (i.e. that part of the total IgE which is directed against a certain allergen). This kit is known as the RAST (= radio-allergosorbent test). Originally all these kits used radioactive compounds.

After the introduction of the ELISA (3) (= enzyme linked immunosorbent assay), in which the radioactive label is replaced by an enzyme, this method was also applied to the detection of total and specific IgE $(4,5,6)$. Recently these methods have been introduced commercially. In this investigation the commercially available RIA kit will be compared with the commercially available ELISA kits.
Materials and Methods

Humán sera

Blood was obtained by venipuncture from normals and patients suffering from bronchial asthma attending the Out-patient Department of Pulmonology at this hospital. The blood was allowed to clot at room temperature and the sera were stored at $-70^{\circ} \mathrm{C}$ until use. None of the sera were stored longer than one year.

\section{Reagents}

For the determination of total serum IgE the PRIST-kit (RIA), the Phadezym-PRIST-kit (ELISA) (both from Pharmacia, Uppsala, Sweden) and the Enzygnost-kit (ELISA) (from Bchringwerke AG, Marburg, Western Germany) were used. In the text they will be referred to as A, B and C. Total IgE values were calculated according to the manufacturer's instruction and expressed in $\mathrm{IU} / \mathrm{ml}=2.4 \mathrm{ng} / \mathrm{ml}=2.4 \mu \mathrm{g} / \mathrm{l})$.

For the determination of specific serum IgE the RAST-kit (RIA) and the Phadezym-RAST-kit (ELISA) (both from Pharmacia, Uppsala, Sweden) were used. In the text they will be referred to as D and E respectively. The patient's sera were subjected to the following allergen panel: house dust $\left(h_{2}\right)$, cat epithelium $\left(e_{1}\right)$, dog epithelium $\left(e_{2}\right)$ and Lolium perenne $\left(g_{5}\right)$. All allergen paperdiscs were purchased from Pharmacia Diagnostics AB, Uppsala, Sweden (allergen codes between the brackets). The specific IgE valucs are expressed in $P R U / m$ as suggested by the manufacturer (PRU/ml = Phadebas RAST Units $/ \mathrm{ml}$ ).

All reagents were prepared freshly before usc.

For further details sce table 1 . 


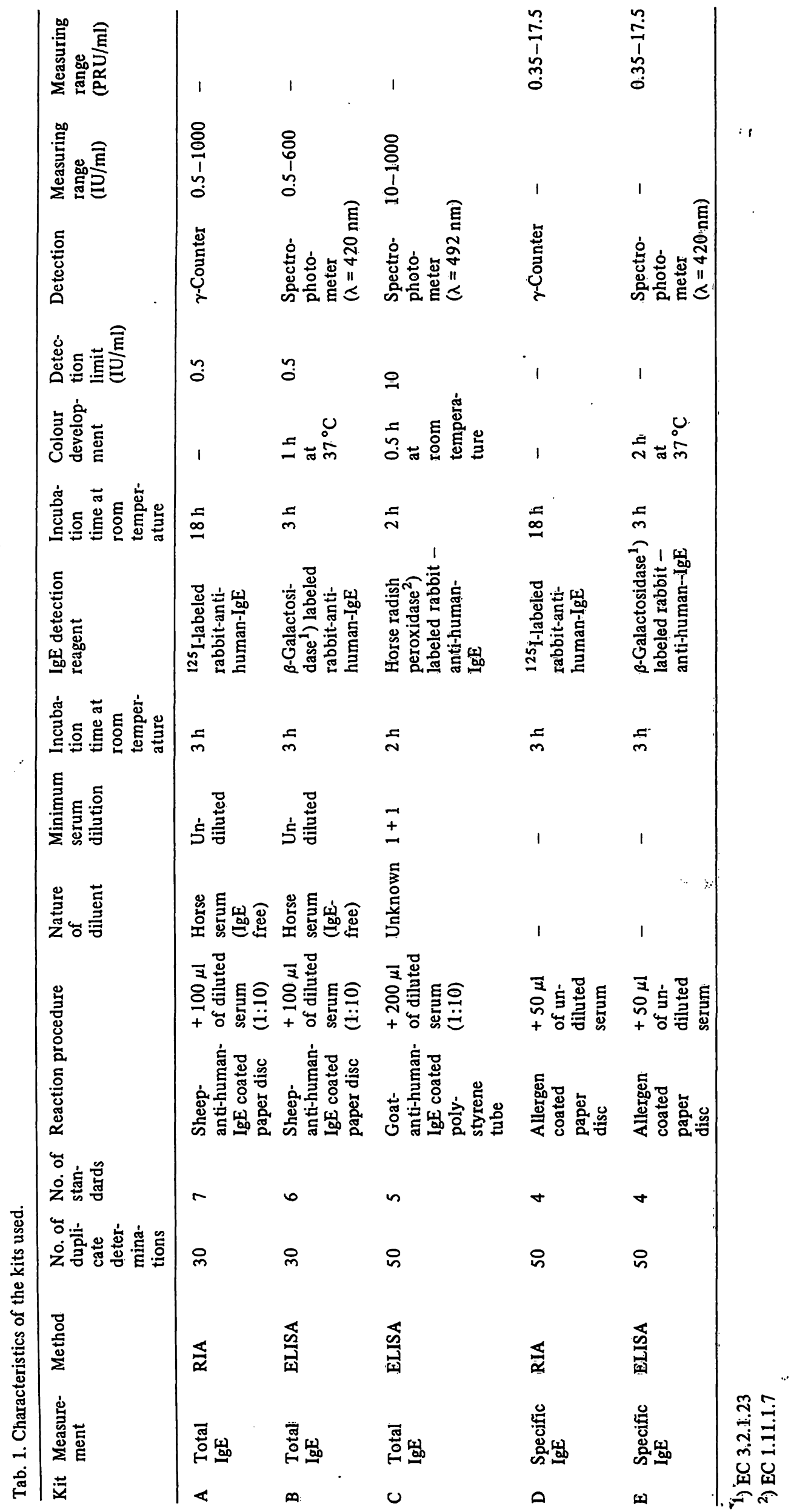




\section{Results and Discussion}

It has to be underlined that ELISA methods need only simple equipment, and do not use radioactively labelled compounds which may need a special licence and special laboratory precautions. Although most laboratories are already fully equipped for the handling of radioactive materials, the ELISA system may be chosen to prevent further environmental pollution.

\section{Total IgE determination}

The results of the total IgE determination in different sera obtained by kits $A, B$ and $C$ are presented in figure 1 .

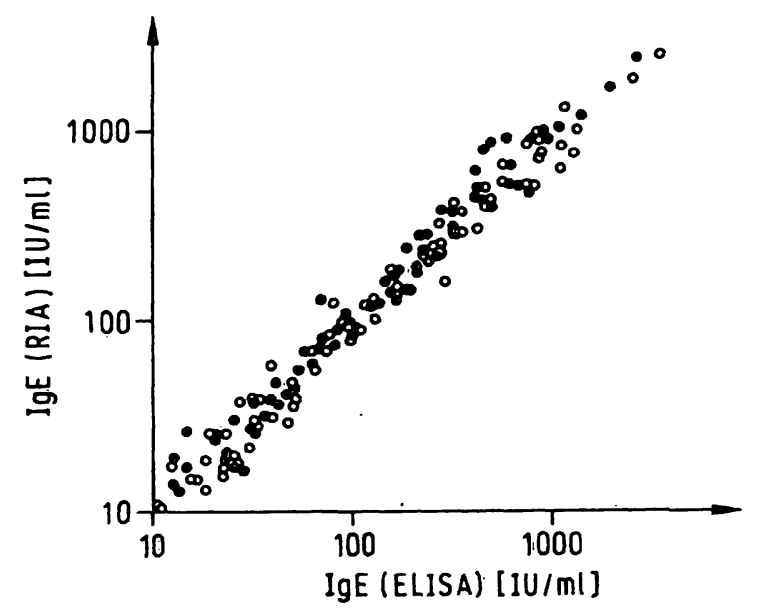

Fig. 1. Correlation of total IgE serum values (in $\mathrm{IU} / \mathrm{ml}$ ) assayed by RIA (kit A) and by ELISA (kits B and C).

Spearman rank correlation coefficients:
$(\bullet) R_{A-B}=R=0.99 \quad n=72 \quad p<0.0001$
(o) $R_{A-C}=R=0.99 \quad n=72 \quad p<0.0001$
$R_{B-C}=R=0.98 \quad n=72 \quad p<0.0001$

From figure 1 it will be clear that both ELISA methods correlate well with each other and with the RIA method. In figure 1 only serum levels above $10 \mathrm{IU} / \mathrm{ml}$ are plotted, since the manufacturer of kit $\mathrm{C}$ recommends against the use of slightly or undiluted sera for the determination of IgE values. Since kit $C$ has a detection limit of about $10 \mathrm{IU} / \mathrm{ml}$, immunodeficiencies may not be detected.
The inter-assay coefficients of variation of kits A, B and $C$ are $6.2-10.8 \%, 7.3-11.9 \%$ and $7.7-12.2 \%$. respectively. The intra-assay coefficients of variation of kits $A, B$ and $C$ are $5.8-10.2 \%, 6.7-10.9 \%$ and $6.5-11.3 \%$ respectively. These data were calculated from the results obtained in five different experiments. In each experiment 4 sera with different $\operatorname{IgE}$ content were examined in triplicate.

Addition experiments were performed with kits B and C. Standard solutions of both kits were added to the same standard pool $(150 \mathrm{IU} / \mathrm{ml})$. The results obtained were expressed as the percentage of the expected value. Both kits showed equally good results with recoveries between $86-110 \%$.

In our opinion all tested kits are suitable for the detection of total IgE $>10 \mathrm{IU} / \mathrm{ml}$. No great differences were found with respect to precision, accuracy, stability, ease of handling and simplicity.

\section{Specific IgE determination}

The results of the specific IgE determinations obtained with kit $D$ and kit $E$ are shown in figures $2 a, b, c$ and $d$.

Figures $2 a, b, c$ and $d$ show a reasonable correlation for most allergen paper discs, although the measuring points are not always equally distributed. Especially in figures $2 \mathrm{~b}$ and $\mathrm{d}$ some PRU values suggest a bad correlation. Although this finding cannot be explained, it must be remembered that RAST is a rather qualitative measure. When RAST classes ( 1 to 4 ) are compared instead of PRU units, the correlation is quite good. Clinically only RASTclasses $>1$ are of some importance, when related to skin test results. Furthermore with both kits the same sera were found negative for all tested allergens $(n=10)$.

Although the comparison between total IgE and specific IgE RIA and ELISA kits was performed on only a limited number of sera the authors think it is valid to state that it is not possible to recommend a particular kit. The choice depends on the equipment and licence of the investigator. 

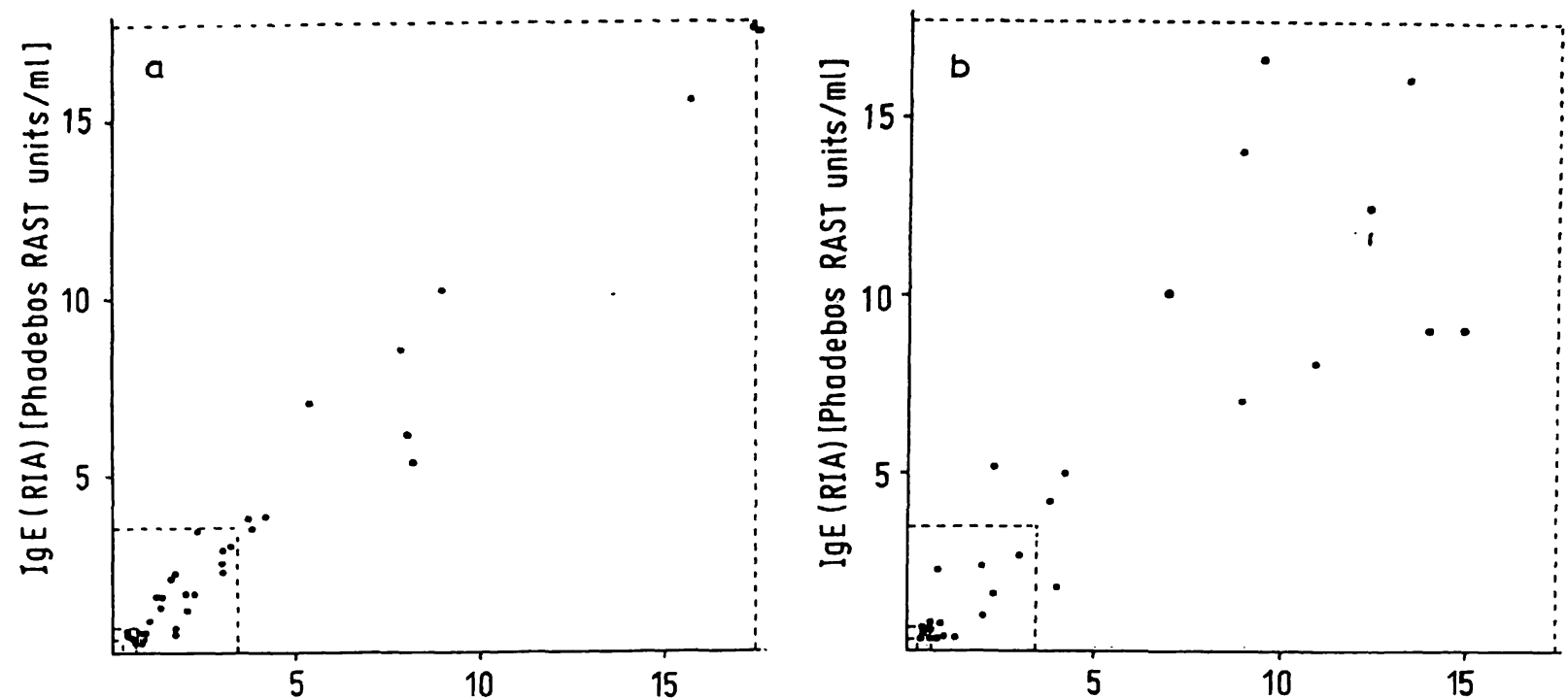

IgE (ELISA) [Phadebos RAST units/ml]
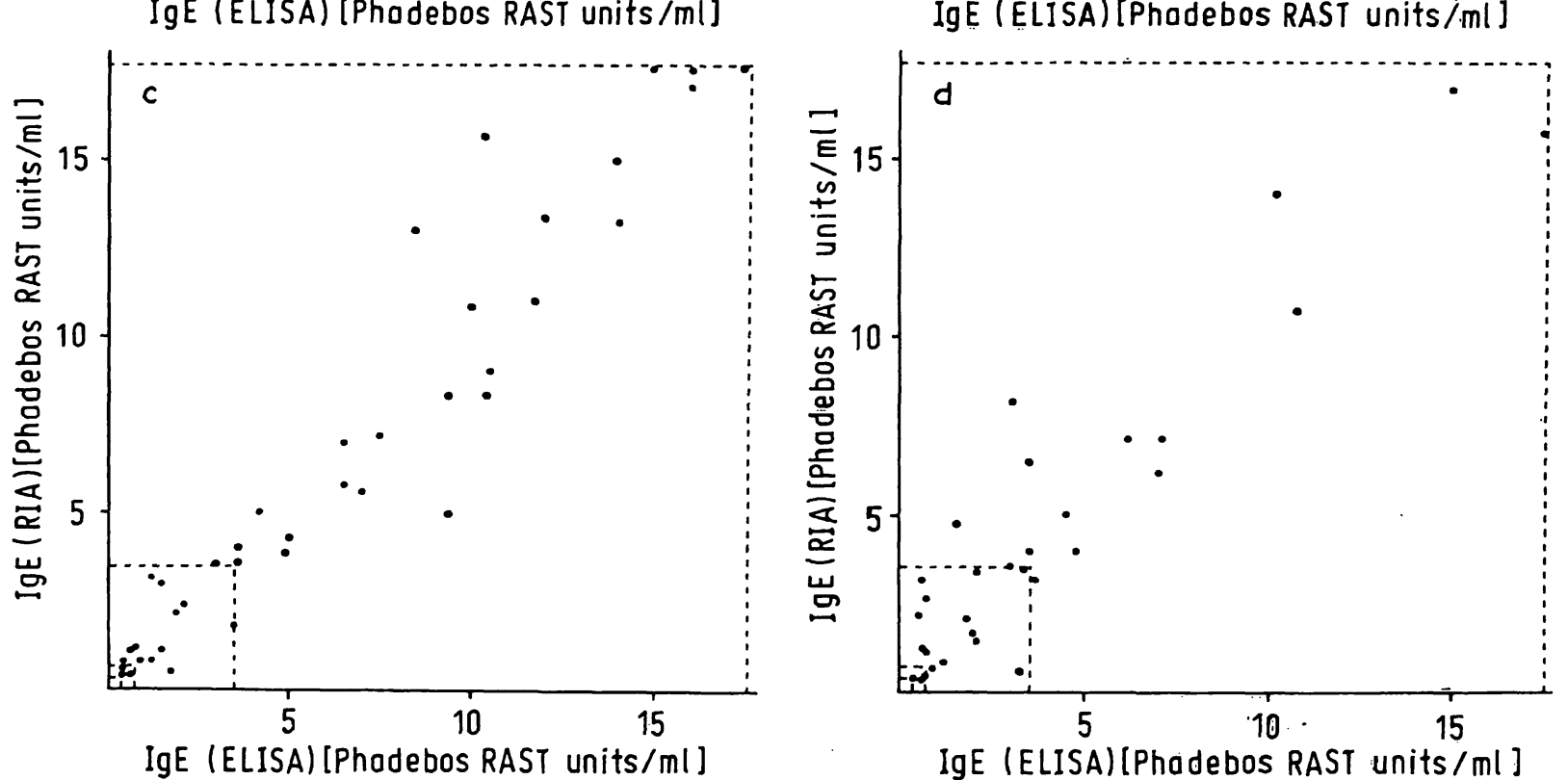

Fig. 2. Correlation of specific IgE serum values obtained by RIA (kit D) and ELISA (kit E) using 4 different allergen coupled paper discs.

Spearman rank correlation coefficients:

a: cat epithelium: $R=0.99 n=36 \quad p<0.0001$

b: dog epithelium: $R=0.82 \quad n=28 \quad p<0.001$

c: Lolium perenne: $\mathrm{R}=0.94 \mathrm{n}=40 \quad \mathrm{p}<0.0001$

d: house dust: $\quad R=0.80 \quad n=31 \quad p<0.001$

The dotted lines indicate the RAST classes: values below 0.35 Phadebas RAST units $/ \mathrm{ml}(=$ class 0$)$ are considered negative (are not shown).

class $0<0.35$ Phadebas RAST units $/ \mathrm{ml}$

0.35 Phadebas RAST units $/ \mathrm{ml}<$ class $1<0.70$ Phadebas RAST units $/ \mathrm{ml}$

0.70 Phadebas RAST units/ml < class $2<3.50$ Phadebas RAST units $/ \mathrm{ml}$

3.50 Phadebas RAST units $/ \mathrm{ml}<$ class $3<17.50$ Phadebas RAST units $/ \mathrm{ml}$ class $4>17.50$ Phadebas RAST units $/ \mathrm{ml}$

\section{Acknowledgement}

The authors thank Mrs E. E. Serra-Kalis for typing the manuscipt.

\section{References}

1. Kjellman, N. I. M., Johansson, S. G. O. \& Roth, A. (1976) Clin. Allergy 6, 51-59.

2. Merrett, T. G. \& Merrett, J. (1978) Clin. Allergy 8, 543-557.

3. Engvall, E. \& Perlmann, P. (1971) Immunochemistry 8 , $871-874$.

4. Hoffmann, D. R. (1973) J. Allergy Clin. Immunol. 51 303-307.

5. Guesdon, I. L., Thicrry, R. \& Avrameas, S. (1978) J. Allergy Clin. Immunol. 61, 23-27.

6. Weltman, J. K., Frackelton, A. R., Szaro, R. P. \& Rotman, B. (1976) J. Allergy Clin. Immunol. 58, 426-431.

$$
\begin{aligned}
& \text { Dr. P. Bruynzeel } \\
& \text { Dept. Pulmonary Diseases } \\
& \text { University Hospital Utrecht } \\
& \text { Catharijnesingel } 101 \\
& \text { NL-3511 GV Utrecht }
\end{aligned}
$$

